\title{
Expressions of Duress on Facebook by Chadian Urban Youth in the Diaspora and
}

\section{N'Djaména}

\section{Mirjam de Bruijn}

This is a post-print version of Mirjam de Bruijn (2018), Expressions of Duress on Facebook by Chadian Urban Youth in the Diaspora and N'Djaména [connecting in times of duress] (translation: Bruijn M.E. de), Conflict and Society. Advances in Research 4(1): 259-274.' available online at https://doi.org/10.3167/arcs.2018.040119.

\begin{abstract}
Africa is at the lower end of internet use, but Facebook connectivity is rapidly increasing, linking diaspora and local people in mainly urban regions in Africa. A survey conducted in N'Djaména revealed that 1 in 10 people uses Facebook, which is an important platform for these connected Chadians to express feelings, write thoughts, and create networks (i.e., to create a social life). In countries where daily conflict, oppression, insecurity, and mistrust pervade social life, posts and messages engage with these circumstances in a certain dialogue, which can be understood as an expression of duress. This article follows three Facebook users from both the diaspora and N'Djaména, and I position their Facebook expressions and actions in the context of their personal lives in contemporary Chadian political and connectivity history. Facebook appears to be an escape route from the reality of duress, and a form of practical action coupled with political agency.
\end{abstract}

Keywords: Chad, connectivity, political agency, social media, youth

It is after all clear that fear has definitively changed camps and that the regime of Idriss Déby experiences much more fear than the Android youth that we are. ${ }^{1}$

This quotation is from a 16 February 2016 post by "Fils-de-Maina" (a Chadian internet activist) 
after a period of intensive Facebook interactions in the lead-up to the 10 April 2016 presidential elections in Chad. His hypothesis was confirmed when, after 10 April, access to Facebook, WhatsApp, and other websites and applications was shut down inside Chad. The government's explanation that this was because of technical problems was unpersuasive. Most of the people I spoke to were convinced it was a political measure taken by that same government, a government that is experienced as oppressive by many of the urban youth I worked with in N'Djaména and the diaspora.

This incident was a moment in Chadian history when the youth took power (temporarily) over the public sphere and launched various forms of protest against a regime that they felt had been neglecting the needs of the population for too long. November 2015 to April 2016, the period before the presidential elections, saw an upsurge in political protest actions. Iyina, one of the new youth movements that were formed in this period, literally means "we are tired." These protests were geared against the regime of Idriss Déby, who has been president of Chad since 1990. Chad's political context is defined by a seemingly endless situation of near-conflict / civil war and regimes of oppression. Marielle Debos (2016) has sketched this environment, where people are constantly under arms or under the threat of new conflict. Chad still lies near the bottom of development, poverty, and corruption indexes_-for example, position 186 of 188 on the Human Development Index (UNDP 2016: 205) and 159 of 176 on the Corruption Perceptions Index (TI 2016: 4). Such conditions of longue durée crisis lead to the normalization of a crisis that influences daily realities almost unconsciously. How do people live such a life in duress (de Bruijn and Both, this issue)? In this article, I research the relationship between living in duress, social media and information and communication technologies (ICTs), and the political agency of Chadian youth. 
After Howard Rheingold's (2002) publication of Smart Mobs, others that related protest and political movement to ICTs and connectivity soon followed. Sokari Ekine's (2010) edited collection SMS Uprising and Adam Branch and Zachariah Mampilly's monograph Africa Uprising (2015) defined the third period of political movements in Africa, this one embedded in a digital environment ${ }^{1}$. Linda Herrera (2012), Akin Iwilade (2013), Ariadne Vromen and colleagues (2015), and Yannis Theocharis and Will Lowe (2016) refer to African youth as central players in this digital epoch. Social media have evidently created a space for the expression of political discontent, a space that was previously unavailable or impossible. In this article, I examine, first, how social media is a platform for expression and exchange about the politics of power and, second, how this creates room for action toward social change - that is, political agency (cf. Chabal 2009; Kaun et al. 2016). Do the youth indeed "gain ground" in Chad, as is suggested in Fils-de-Maina's post? Does new connectivity lead to an exposure of living in duress and hence create a momentum of protest?

The youth who are central to this article can indeed be labeled "Android youth." They are urban youth for whom the internet, especially social media, has become an indispensable part of their lives, even though this phenomenon is very recent. The main medium for the youth is Facebook, which has become firmly established in Chad only since 2009 (see Seli 2014). Is this new platform of expression a form of "escape" from political realities for this young, a platform on which to vent their frustrations? Does it function merely as an escape valve to mitigate living the hardship of everyday life, or does it also function for the youth as an incentive to act and to initiate political actions on the ground? Experiences of hardship, of living in duress, are not the same for everybody. The urban and Android youth at the center of this article are not

\footnotetext{
${ }^{1}$ The first period was the time around independence, the second started in 1990 with the democratisation and decentralisation politics, imposed on African governments by the international organisations.
} 
experiencing the same realities as the urban non-schooled poor, but they are, in general, leaders in their society and give voice to the conditions experienced by others.

In this article, I analyze the period just before the Chadian presidential elections in April 2016, in terms of both off- and online activity. This episode presents a good opportunity to understand the political agency of young people and how it is fueled through new connectivity. I followed three Facebook users at different moments of tension from January to April 2016. One of the three, Fils-de-Maina, is a self-proclaimed tchactiviste ${ }^{2}$ living in Paris; the second, Z., is an unemployed student living in N'Djaména and a prominent member of the youth organization Iyina; the third, C., is a Chadian slam artist ${ }^{2}$ and medical doctor who lives between Chad, Cameroon, and, since May 2016, the Netherlands, where he is pursuing his $\mathrm{PhD}$. They are all relatively well known among a large proportion of the educated Chadian youth in different Chadian cities and in the Chadian diaspora.

Before I present the off- and online actions of these young men, I will first reflect on my methodology, my position as a researcher in this field, the choices I made. Following this background, I will present the actions of the three main figures and analyze what their political agency is in duress and in the epoch of connectivity. Then, I will sketch an additional background to connectivity and the world of duress as expressed in the mediascape in Chad to highlight why Facebook has become important as a means of expression for the youth. Finally, I will reflect on the questions that I have posed in this introduction, including whether there is a relationship between the expression of duress on Facebook, political action on the ground, and the political agency of Android youth in Chad.

\footnotetext{
${ }^{2}$ Activist for the Chadian cause
} 


\section{Ethnography and the Internet: A Note on Methodology}

For this research, I chose an ethnographic approach (Miller and Slater 2001) to understand the use of Facebook in the context of Chadian political developments. Such an approach is by definition holistic. Heather Horst and Daniel Miller (2006) have proposed the anthropology of communication as an approach to the communication embedded in social life. Facebook, the central social medium examined in this article, is not an isolated phenomenon but rather part and parcel of people's lives in a sociopolitical context and has its own history (see also Miller 2011). Such ethnography is an exploration of the complex relationship between local and virtual realities (Coleman 2010). An ethnography of Facebook should include the sociopolitical environment in which Facebook discussions and networks are embedded and how people combine these off- and online worlds in their lives. However, the texts and discussions created in the online world can also be analyzed as part of social and political discourse (see Wasserman 2010). Such an approach is complementary to the ethnographic observation and participation approach, and I followed both paths in this research. In this ethnography, I chose a biographical approach, of giving detailed and in-depth accounts of a person's life, situated in this case in a specific time span that covers an interesting political event. The three young men I present in this article each represent a specific element of the virtual community of which they are part and of the offline positions in the political action field of Chad. Their actions and reflections on Facebook and on the ground give us an interesting insight into how they use the online platform/community to live with the harshness of life in Chad.

The case studies and biographies I present in this article are part of a long experience of research in Chad. I began with an initial research project in 2001, questioning the postcolonial history of war and civil unrest (de Bruijn 2008, 2014; de Bruijn and van Dijk 2007). In 2014, I 
encountered a different atmosphere in Chad, and I had grown into a different kind of researcher. This time, I delved into the position of young people, and I encountered many young people who were trying to get their voices heard to protest the oppressive government under which they felt they had no opportunities. From March 2014, I engaged in research on music, art, and activism in Chad (de Bruijn and Lalaye 2016). One reason for this change in orientation was the advancement of ICT in the country. Djimet Seli (2014: chap. 9), who undertook research (20082013) on mobile telephony in Chad, followed the increasing internet connectivity transformations, among which internet discussion groups were then a novelty. This "new" connectivity and the technological changes also influenced other domains in society—such as the urban music scene that now, with digital equipment, became far more productive—and intensified the relations between the diaspora and local Chadians. Social media and digital music were thus added to my "field." I anticipated that the youth would express themselves about their experiences, including their confrontation with the political atmosphere in their country. To understand if and how this took place, I then decided to follow the discussions on Facebook held by some of my on-the-ground informants, taking screenshots of their Facebook posts and becoming one of their chat/WhatsApp contacts. I also shared part of their lives in Paris, N'Djaména, Cameroon, and the Netherlands.

Research into present-day political actions in an oppressive environment raises ethical questions. What are the risks for the "informants" and the researcher? I asked consent of the three activists, who argue that their visibility in Chadian society, and hence in this article, is part of their political presence and actions. Nevertheless, I do not want to bring them into danger and so do not provide their names. However, an artist, a cyber activist, and leading person in Iyina are in fact public figures. Anybody can trace their posts, which, once posted on their public 
Facebook pages, are public. Because of their position as protesters and educated youth, they have more opportunities than most Chadians do. In a way, they are the voices of the Chadians who live in duress. As I will explain later, the mediascape in Chad allows voices to speak as long as they do not touch the regime. And, as will also become clear, the regime is in charge: it closed internet access and arrested several leaders of the movements in order to control the situation shortly before the elections. Although Fils-de-Maina asserted that fear had changed camps, the period that followed his post shows the contrary.

\section{Facebook Actions in February 2016}

With the forthcoming elections of 10 April 2016 and the imminent beginning of the election campaign (end of March), tensions were rising in N'Djaména in February. Nearing election time, there is a rise in political conscience, because of the campaigns, and hence visibility of politics in the streets, and because of the measures taken by political actors. In the case of Chad, these measures were not always very popular. For instance, when the government took rigorous measures to handle the financial problems they foresaw, one measure was to reduce the number of youth who could integrate into state services. The youth interpreted this as another limitation on their possibilities to build a future and consequently criticized the government. The recently revived youth organizations were very clear in their wish to protest against this measure. In N'Djaména, an announcement of a demonstration to be held on 2 February was made. One of the leading organizations was the Collectif des Associations et Mouvements de Jeunes du Tchad (CAMOJET), the Collective of Associations and Youth Movements of Chad established in 2004, of which Fils-de-Maina and C. were founding members. CAMOJET is today an established organization that works for human rights issues, youth, and peacebuilding. It states explicitly that 
it is not political (see, e.g., Camojet Tchad 2018; Peace Insight 2015). Another active organization was Iyina, established in January 2016 and headed by a student union leader who had been arrested in 2015, when Z. became involved in the organization. C. is also a member of this movement (de Bruijn 2015).

The youth were ready to go onto the streets. The government, however, banned this demonstration, which was considered a humiliation for the youth. Actions had to follow. Fils-deMaina played an interesting role here: he (from his base in Paris), along with young leaders in Chad, initiated new protests. They called for demonstrations to shake a fist at the government and provoke the authorities in the hope that arrests would be made. The leaders expected these demonstrations to be small, as only a small number of youth would have the courage to take to the streets, but hoped that arrests would at least awaken the international community. They called for new demonstrations for 6 February. From Paris, Fils-de-Maina spoke extensively by phone with the youth and their leaders in N'Djaména (he claims he had a phone bill of more than 1,000 euros). But the leaders were especially active on Facebook in criticizing the government measures and calling for action.

In the post "Marche Républicaine Tchadienne," Fils-de-Maina calls for action in both the diaspora and Chad (post 1). His Facebook posts have a moralistic tone: they point to citizens' rights, and he speaks of liberation and of the suffering of the youth (la crise). The responses to his posts on this demonstration were mixed (post 2). Many Facebook users supported the actions, referring to the demonstrations in Burkina Faso and to other moments of political change through youth movements in Africa. A few doubted Fils-de-Maina's intentions, but they were this time in the minority. Other events showed much more violence in the Facebook exchanges. This illustrates the different groups present among Chadians, ranging from those in favor of and those 
against the Déby regime. The online presentations and actions reflect reality on the ground, which is why it was remarkable and probably a sign of unity that the reactions in this case were largely supportive of Fils-de-Maina's posts.

\section{Post 1}

(5 February 2016)

"Marche Républicaine Tchadienne"

The demonstrations that are foreseen for Saturday, 6 February are citizen actions. They are open to all people who are sensitive to the crisis situation that the youth in Chad are facing.

All citizens, either in Chad or outside, should organize and join with other youth to demonstrate for change of the law of finances that stops all integration in public service in 2016.

For N'Djaména, the location for gathering will be announced from here this evening for reasons of security.

For Moundou, we will meet at 7:30 in front of the governor's residence.

For Sarh, 7:30 in front of the governor's residence.

Abéché, 7:30 in front of the governance house.

For Paris, the meeting is planned for 14:30 at the Place de la République and is not under the banner of any particular political organization. On the contrary, all Chadian associations, political parties, and organizations are invited to join.

\section{Post 2}


(5 February 2016)

Responses to "Marche Républicaine Tchadienne" (post 1)

Response 1: The Chadian youth is going to win; it is enough to join with all means in order for the youth to liberate itself.

Response 2: Why only in Chad and France? But we will be with you with all our heart. Fils-de-Maina: All can join; we are happy to see you join as well, take up contact with $\mathrm{HH}$.

Response 2: Thanks, we already did.

Response 3: Let's take the example of Burkina Faso.

These Facebook posts and numerous phone calls were followed by action, and small demonstrations did indeed take place in N'Djaména and other cities in the world (see, e.g., Bertho 2016). The Chad regime's reaction was predictable and even more than Fils-de-Maina had hoped for: the leaders of the civil society organizations were arrested. Fils-de-Maina evaluated this action (in a messenger exchange with me on 5 October 2016) as being successful. The attempt to disturb the regime had achieved its goal. A combination of diaspora activism, Facebook messages, and mobile phone calls had mobilized angry Chadian youth and resulted in clear political action.

For those on the ground in N'Djaména, such actions are simultaneously full of danger and anxiety. This is not to say that Fils-de-Maina himself can act without consequences. As a political asylum refugee in France, he is closely monitored. After his actions on Facebook, he was summoned to present himself at the Embassy of Chad in France to be arrested, a summons that he ignored. It is also known that the Chadian secret service has informants in France. 
Nevertheless, Fils-de-Maina is convinced of the justice of his actions, perhaps also because he considers himself an activist: he lives for it.

Being an active opponent/activist on the ground in Chad is not easy, as we can read from the stories of Z., a self-proclaimed activist in N'Djaména. He is active on Facebook and has developed his own blog. He has an education in graphic arts and had a job with an editing house when I first met him. He left his job to study law. For his blogging and webmaster arts, he followed a course in Cameroon in 2014, to which a youth organization invited him. ${ }^{3}$ The blog has never become very widely read, and the reasons seem obvious: too much government control and Z.'s hesitation to publish much material. ${ }^{4}$ More explicitly than does Fils-de-Maina, he reflects on the regime and his country's sociopolitical situation, but he does not call so actively for action. He did, however, participate in the demonstrations of 6 February 2016 personally/physically. He is one of those youth who are part of Fils-de-Maina's "calling" group. He is radical in his explanations. The following quotations (post 3) are from his posts, in which he comments on what happened and reflects on other Facebook comments.

\section{Post 3}

(5 February 2016)

President Déby, tell your police to stop humiliating the demonstrators. Tell those who lead the national police to read the introduction to our Constitution. Good leaders behave in a humane way toward their people. After their death, it is not only their people who remember them but the whole of Africa, the whole world. Fighting body and soul for all, for the betterment of the poor, demanding a justice before which the rich and the poor, the strong and the weak, feel equal—-those leaders merit remembrance. 
(8 February 2016)

A voting card does not feed a hungry person. Our politicians must think beyond their announcements about the arbitrary arrests of the youth at this moment. We expect more from them than this .... The artist musicians must break the silence. I remember performances, clips, and songs here and there against Boko Haram in Chad, which is very good. But the real Boko Haram in Chad is right in front of us; it is called BAD GOVERNANCE. Let's fight it together!

In this post on Z.'s blog, he refers to the musicians he expects to play an engaged role in society. The fact that they are so absent prompts him to call for their presence. This post also alludes to the shared idea that the Chadian government tries to co-opt musicians by "buying" them for its own purposes. For Z., the musicians who composed a song to commemorate the attacks by Boko Haram in June and July 2015 should just as well sing about bad governance.

C., a doctor and a slam artist, never entered these dynamics. He has his own strategy for engagement and avoiding the dynamics of co-option. He is a well-known "slammer" in Chad and Central and West Africa and very much involved in the development of slam in his country, although he has lived most of the past few years abroad. As a slam artist and festival organizer, he is well known among the young and old in N'Djaména. He was, like Fils-de-Maina, a founder of CAMOJET, and he supports some of the other organizations. He takes up a position as an observer, watching the others and providing comments and advice when called on for input. Around this first week of February 2016, he was also posting. His posts never directly attack the regime but rather are poetic and always carry a strong message (post 4). Nevertheless, his 
wording indicates a lot of anger and deep thought about Chad's political and social situation. His posts immediately draw many reactions; most posts attract 180 to 300 "likes" and up to 150 comments that often involve serious discussions about the situation in the country.

\section{Post 4}

(5 February 2016)

One does not put down a revolt of hungry people by hitting them, but instead by giving them something to eat. Beat, beat; but as long as I have energy I will cry out my hunger!

(7 February 2016)

If liberty is from now on forbidden in Chad, they should make it clear to us. If this is not the case, our brothers should be released, whose only mistake was that they believed they live in a democratic country.

These three young men who expressed themselves on Facebook during the same time—a period of oppression and of disappointment for the youth—did so in different styles and probably with different effects. They are friends who exchange among themselves and criticize each other's actions. Before we enter a discussion of their differences, I will present a Facebook post related to another event, when many Chadians all over the world became involved in Chadian politics in response to the rape of a student.

\section{\#jesuiszouhoura}

A second episode in the Facebook history before the elections in April began on 8 February 
when four young men, sons of highly placed officials (three generals and a minister), raped a female student named Zouhoura. The hashtag \#jesuiszouhoura became central for a few weeks in Facebook posts about Chadian politics. What happened? Rape is unfortunately a common phenomenon in Chad and, as my informants explained to me, part of cultural practice. In an urban setting, such practice is no longer tolerated. However, the young men who violate a young woman are often protected by their highly politically placed family members. On 8 February, the young men also filmed their acts and shared the video with friends. The video fell into the hands of a female friend of Zouhoura, who sent it to Fils-de-Maina, who then posted the video on Facebook for a few hours - just a few hours because he did not wish to offend Zouhoura too much, but he was convinced that this video would help the fight against the violation of women in Chad. The film did not, of course, show a very nice scene. Reactions were overwhelming, the hashtag went viral, and Chadian people protested all over the world, supported also by their nonChadian friends. This outcry exerted pressure on the government, which could no longer deny this practice, and it was forced to act.

Fils-de-Maina did not stop here: he organized an interview with Zouhoura's uncle and later with Zouhoura herself and posted all the facts around the case. His posts were always in a wording that, while exposing the facts, was also a complaint against the government. For instance, in this post (post 5), he announces that Zouhoura was forced to disclaim the whole affair in front of the national cameras. He turns the affair now into a national and even worldwide protest.

\section{Post 5}

(15 February 2016) 


\section{ZOUHOURA URGENT:}

See here a proof of the manipulation and pressure by the Idriss Déby regime, which refuses to permit the people to have a voice and go onto the streets.

Thanks to the publication of the video this morning, look how they urge the young Zouhoura to call for calm and to cancel the demonstrations.

1. Where have the police and the state been since 8 February when Zouhoura was abducted and raped?

2. Why wait for me to publish the video, so that all people were shocked and ready to go onto the streets to react?

We will not cancel this march and other actions. It is not ZOUHOURA who decides, but the Chadian people.

C., in his poetic style, adds his analysis to the discussions (post 6). In this particular post, he goes quite far, showing his anger by calling for violence, even massacres. This is a shocking call, but Chadians' reactions were quite supportive. This case had gone too far.

\section{Post 6}

(14 February 2016)

Their parents have robbed us for decades. Their children rape our daughters. When I see what has happened to Zouhoura, I think of my daughter .... If these bastards are not punished, let's make their life difficult. Let's lynch them! I know that their parents will do everything so that they will leave the country, or they will put pressure on the judiciary system so that they leave them to live in peace; but wherever we meet them, 
let's be ready to attack them, to massacre them. If some people do not respect their oaths, we will not respect ours.

So, indeed, many people took to the streets, from the north and south, men and women, young and old. In this case, I was often online (using a messenger application) with Z., who informed me about the different protests in which he often participated. Solidarity protests were organized in China, Paris, Canada, and elsewhere. The pressure on the Chadian government was high, and it did eventually arrest the four young men, showing them on national TV, but their final sentence was not particularly high, and they were free soon after. Zouhoura was allowed to leave Chad and went to Paris, where she was well received in front of the media and Fils-de-Maina again made a report on Facebook.

Z. was rather silent on Facebook about \#jesuiszouhoura, but one can find on his page all of Fils-de-Maina's posts and videos and C.'s few posts. Perhaps Z. was silent because he was too busy protesting on the streets. These were hectic times in N'Djaména (post 7).

\section{Post 7}

(15 February 2016)

Every week, every day there is something national that frustrates the Chadians. The end of the regime is there, but it is catastrophic. As someone said: if this regime loves Chad, they must raise the white flag and leave others to take the lead for a better future.

THAT JUSTICE BE DONE FOR ZOUHOURA!

Despite all this attention, the police again suppressed one of the last street demonstrations in 
Zouhoura's case, and another victim was created: a teenage boy was killed. His memory became the closure to the Zouhoura story but triggered a call from Fils-de-Maina to no longer support the current regime (post 8).

\section{Post 8}

(15 February 2016)

ASSASSINATION:

After they violated Zouhoura, see how the police of Déby have just killed a young innocent who was on the street demonstrating his indignation. See how the regime of Déby and his police assassins behave!

This young boy is only 15 years old and was called HASSAN ABACHOU.

Enough is enough, we will no longer accept this, and we will mobilize to say STOP to the violations, massacres, and other horrifying things done to our poor citizens who ask only for social justice.

We will demonstrate in the coming weeks everywhere in the world, and let solidarity rule!

A concert held at the Institut Français du Tchad in N'Djaména the next month could be considered a direct follow-up to the Facebook actions. This concert, headlined by C., was clearly a response to all these events. Among C.'s new songs was “\#jesuiszouhoura," which made a huge impression and was enthusiastically supported by the audience. The hall in which the concert was held was packed with people, and everyone acknowledged and actively participated in what was a form of commemoration. The concert was like a recapitulation of the events in 
February, again uniting people around their rejection of the ruling government.

On 28 March 2016, the presidential election campaign officially began, as if nothing had happened.

\section{Facebook Actions and Relations}

How are these two Facebook "events" expressions of duress - that is, of internalized hardship? The three young men I have taken as main actors have their own ways of experiencing and responding to the Chadian circumstances of duress. They also make deliberate choices about how and when to post on Facebook about the events that are important to them. It is not a random affair. They deliberately intend to bring about political and social "change," and Facebook is one of the means they use in their attempts to exert influence. In their posts, we have seen references to the actions of state agents, to events that caused reactions of anger, to injustices inflicted on Chadian citizens, to feelings of outrage and indignation. The Facebook posters express their moral and political indignation and show their moral standards as different from the standards of those they perceive as oppressors. Their online shares are clearly intended to communicate this anger, which is one of the expressions of duress.

Among the Facebook posters, C. is the most eloquent in his use of language, and his words provoke strong emotions and have the power to move people to action. His songs also reflect this: he provides listeners with thoughts to ponder and hence a change to analyze their own situation. In discussions, he always takes the point of view of someone who analyses, although he turns bitter and angry in some cases - as was clear in his posts about Zouhoura. He is a well-educated young man, a medical doctor. Since high school, he has been known as a critical mind and was already back then criticizing the circumstances in Chad in his rap lyrics. 
During his period of study, he was expelled for two years for participating in a protest at his university. He still feels that injustice is rampant in Chadian society today. In addition, his work as a medical doctor has brought him into contact with severe poverty and corruption, which continually trigger his anger. His international success as an artist makes him a well-known person in Chad, and his songs are popular not only with the youth but also with elders.

Z. is a law student, but since his university is barely functioning - there has been a general strike for several months in response to state cuts in university salaries and a moratorium on scholarships - he has considerable free time to devote to his activism. He uses the internet to promote change and tries to do so from N'Djaména. To access a fast internet connection, he often travels to Kousséri, the Cameroonian town on the other side of the river (N'Djaména is situated at the border with Cameroon). He also combines his internet actions with participation in the demonstrations that he comments on, and he is a real activist on the ground. His experience of duress is closest to the lifeworld of the "ordinary" urban youth in N'Djaména. On top of this, Z. is an orphan and often feels lost in the hectic modern world, where he rarely experiences a feeling of security.

Fils-de-Maina is explicit in his wish to realize a "change," a "revolution." He explained to me that his actions have become more intensive with the increasing opportunities of social media, but he has been active in this field ever since he was a young boy and on the internet since 2003. These days, he spends at least a third of his salary on these actions. He is unable to return to Chad, and the government has threatened him several times. His experience of the causes of duress is, compared with the others, more related to a history of activism and opposition. He spent his youth in Benin, where his father fled with his family for political reasons; his father was opposed to the regimes of both Hissène Habré (1979-1990) and Déby. 
For Fils-de-Maina, being an activist is almost a family affair. The fact that he cannot live in Chad makes him sad. His mother now lives there. However, he is also proud of being a tchactiviste and has turned it into his living and being.

These three young men are shaped in contexts of duress. They are all confronted with the long history of conflict in Chad, most clearly so in Fils-de-Maina's case. C. often commented that conflict was not always everywhere. In his youth, he lived in a part of Chad where war violence was not present in literal fights or clashes. However, no area in Chad escaped the regime of dictator Habré in the 1980s, or the atrocities of the Déby regime. These three young men have grown up in a period with Déby in power and have witnessed many injustices on national and regional levels, as well as in their own social environments. They have also been touched by the more indirect consequences of the dictatorial regime in early deaths of parents, periods of hunger, and problems finding a job or the impossibility to study because of strikes.

The two Facebook events show that the Facebook posts interact with and lead to practical actions. These posts and phone calls of Fils-de-Maina and the personal exchanges that C. certainly conducted have likely been able to trigger actions on the ground in which Z. was involved. Their reality of duress is core to their Facebook posts, clearly visible in the words of these three young men. They are leaders in a virtual community and, at the same time, in the community on the ground. Indeed, I consider the Facebook users who interact actively online a community, albeit a "virtual" one. The community interaction in February 2016 was about "news" and information about politics, with some of its members, such as Fils-de-Maina, acting as information brokers, almost citizen journalists. Others participate by reflecting on the situation and providing people with food for thought. The reactions to the different posts show this difference. Hence, the community consists of people who exchange, people who come to the 
pages to inform themselves, and people who actively inform others. These Facebook discussions are also debates and commentaries on the country's sociopolitical situation, and they thereby inform readers and participants in their choices. As such, this is a community and, at the same time, a form of media.

The three young men's political agency has changed through the use of the internet, especially Facebook, and communication. They are political agents and leaders whose agency has also informed action on the ground. They express themselves emotionally on Facebook, which has become a platform for the expression of duress. But does their political agency go further, and what is their position in Chadian society? How do we situate this Facebook development in the more general realities of duress in Chad? Two of these hardships directly influence the possibilities to express duress in Chad: internet access and press freedom.

\section{(Dis)connectivity}

From the case studies presented, we might become rather optimistic about Facebook's influence and its possible power to change society. However, how far does this influence extend, and how many of the 14 million Chadians in the country are reached? For whom is Facebook a platform and medium to express their realities of duress and to respond to hardship?

It is important to note that, starting 10 April 2016, Chad was partially deprived of internet services for eight months. ${ }^{3}$ The government shut down Facebook, WhatsApp, and other specific websites and applications because of "technical problems." None of my informants believe this explanation. These young men and a few women among my informants in N'Djaména have ways to circumvent these restrictive measures, but most of the population does not. Accessing

\footnotetext{
${ }^{3}$ There have since been other, shorter shutdowns following protests (January and April 2018); and until today access to social media is impossible, except to the application VPN.
} 
virtual private networks (VPNs) or configuring connections to internet providers that allow access to supposedly inaccessible websites can only be done with relatively high-tech telephones. Most phones in Chad, especially in the interior and smaller cities but also among most of the N'Djamena population, are unable to do this. Hence, people have no access to these social media websites and services, constituting an important impediment to information flows and communication.

In November 2015, I coordinated a survey in N'Djaména on internet and (smart)phone use. To collect a representative sample, the survey covered seven neighborhoods, selected for their differences in dominant religion, ethnicity, and geographical origin. There were two hundred respondents, and questions were composed in such a way that I could understand if accessing these media would influence the political agency of the people using them. The survey confirmed the general figures on connectivity in Chad: only 17.5 percent of respondents have daily access to social media, and these are predominantly "young" people, as 80 percent of these daily users are between 10 and 35 years old, of whom 56 percent have a smartphone. Computers are rarely used. Respondents spend a mean of 1,000 to 2,000 CFA francs on their phones per week. $^{5}$

Table 1: Politics and Media: Survey among 200 Respondents, N’Djaména $<$ Insert table 1 here $>$

Table 2: Political Actions: Survey among 200 Respondents, N’Djaména <Insert table 2 here $>$ 
Although these results confirm the low internet access and low digital literacy in general in Chad, they also show how Facebook access in this case may influence people's political interests and, in the end, attitudes. The people who access Facebook and the internet confirmed, in the survey's open-ended questions, that they are better informed and might decide to become active - that is, to read more about politics or even to demonstrate. It was also clear that those who answered positively on their use of social media are primarily urban youth, those with a relatively high educational background. However, it has become clear from several interviews and observations that news and opinions travel via links to social and family networks in both the city and rural areas, and these networks in turn influence others. As such, the impact of the information that flows through the internet and social media can be more extensive and influential than the survey results show.

These results also provide further insight into the possible audience of our three informants' Facebook posts. They are part of a select group in the local Chadian and international community of youth and internet users. Furthermore, analysis of public posts probably does not reveal all information, as many young people join closed Facebook groups they hope are private and not monitored. Fils-de-Maina, C., and Z. are also part of closed Facebook groups, where discussions are often more private and political, more direct and interactive. There is a hesitance to react and act in public on Facebook, most probably because of the possibility of being "seen" in these political actions. After all, this is not without risk in Chad.

\section{The Mediascape of Chad and Press Freedom}

For urban Android youth, Facebook as a form of media has become indispensible. They access it easily and free of charge. Furthermore, they exchange news and receive information they can 
normally not access via the ordinary press. Facebook exchange and information has become part and parcel of the mediascape of Chad.

Officially, the press is open and free in Chad, but the reality is different (Waal 2006). The press is basically in government hands. The opposition, independent newspapers Tchadinfo and Abba Garde are widely read in the larger cities but do not reach the rural areas (the chief editor of $A b b a$ Garde was arrested just before the 2016 elections and liberated after three months). The radio is one of the most widespread media formats but is dominated by the national channels. Independent radio stations are permitted, but only with limited bandwidth, and hence do not cover the full national territory. One radio station that escapes this control is 3FM liberté, which ventures to express opinions that have led to its being closed several times over the past 25 years. There are two television channels: national TV and the privately owned Electron TV. However, the private channel is closely linked to the ruling powers, where its financial basis lies. In a March 2014 interview, a former minister of culture fervently defended the position of a government that allowed so many artists to have a platform for their work. However, as C. stated in an interview at that time, "We are allowed to sing, but not on their radio." In short, freedom of the press and voice is quite limited in Chad.

The new media are no less controlled. Although telephone providers are officially private and independent from the state, they cannot obtain a license to operate without a contract with the state. Taxes for these providers are very high, and, according to a personal communication with former personnel in telecommunication services, ${ }^{6}$ the government never pays its own phone and internet bills. This also drives prices up for the common user. Furthermore, the overall coverage is less than 40 percent of the national territory. Internet bandwidth is very low, and areas with $3 \mathrm{G}$ or $4 \mathrm{G}$ connectivity are rare. Nevertheless, Facebook is accessible in an adapted 
form in many phones that are imported from China. Apparently, the content of Facebook is difficult to control, and, although everybody is aware of "spies" in their Facebook exchanges, users consider it a relatively safe space, especially in closed groups - as the survey revealed. This was in 2015, when we conducted the survey, but the situation in 2016 changed, and the eightmonth internet shutdown shows that the space is probably not as uncontrolled as the youth had hoped.

The primary bloggers in Chad are closely followed. The blogger Makaila was expelled in 2009, and he was even followed and threatened in his country of refuge, Senegal. He now lives in France and keeps his blog going with information from many people residing in Chad who publish and provide information anonymously. The recent government blocking of websites could of course not happen without actions by Tigo and Airtel, the country's main internet service providers. They have to follow-up on orders from the government. Freedom of expression in Chad is very limited. This also places Z., as a blogger living in Chad, in perspective: he simply cannot blog too openly.

The following outcry from an anonymous Facebook user is clear (post 9): the government's promises to become more open and transparent are not translated into a reality of connectivity. This non-connectivity is part of living in duress.

\section{Post 9}

(13 February 2016)

Where are we with the project that is to make Chad the "hub" of ICTs?

Where are we with the digital television project?

Wind, only wind!!! [only empty talk] 
Let's go for ALTERNANCE? ${ }^{7}$

\section{Discussion: Conditions of Duress and Realities on Facebook}

The three young men who guided us in this article are living in a world in which the off- and online arenas form their combined reality. They are participating in a connected world that primarily consists of educated urban youth, in both Chad and the diaspora. They experience the hardships of Chad: the feelings of oppression, injustice, and threat of arrest; the lack of internet connectivity, of work, of possibilities to study, of political influence, and so on. The differences in experience of this hardship, of a life in duress, are considerable for Z. (who permanently resides in Chad), for C. (whose presence is on and off), and for Fils-de-Maina (who cannot return to Chad), but they all share a feeling of anger and a will to change matters. Facebook provides them an opportunity to express their emotions and to undertake action. It has also become a platform for socializing and forming a community. Not all Chadian youth participate in this world, but the number of youth participating is growing, and hence its force can increase. The fact that the government has regularly shut down the internet may well be a sign of the new media's potential efficacy as an agent of change.

Is this Facebook activity really a tool for action? Or is it rather an escape route for a small group of young, educated elites? Is it an escape route in the sense that it brings relief from experiences of hardship - a platform for expressions of living in duress, through text and sharing with others? As we have seen in this article, these expressions are not mere rhetoric or discourse. On the contrary, these actions on Facebook are related to actions on the ground: for Fils-deMaina in telephoning contacts and making serious efforts to organize a protest from a distance;

for C. in performing concerts and participating in discussions when he is in N'Djaména; and for 
Z. in being an active participant in street demonstrations. And Facebook is a way to

simultaneously circumvent and challenge the limitations on free expression as they exist in Chad. Hence, we can conclude that Facebook enhances changes in political agency.

We can also conclude that these actors are part of an "effective connective action" that is able to organize movements with a political character (Vromen et al. 2015). The political demonstrations that were organized and appeared without clear leadership are examples of what Alex de Waal and Rachel Ibreck (2013) have labeled hybrid movements. These movements come and go, do not follow clear-cut rules, and often lack identifiable leadership. Yet, Fils-deMaina could be identified as one of the leaders of these actions. These actions are clearly defined in a context of oppression and violence - and hence are realities of duress. The external violence and conflict that are internalized and "create" duress are experienced by the youth as a limitation in their room for maneuver and their rights to have a voice in society. Both the problems with internet connectivity and the lack of freedom of the press are important factors that feed into this experience of duress. Having a voice, a right to be a Chadian citizen with certain liberties, is at the basis of this. As such, the Facebook posts that we have examined are also part of a reorganization of power relations in society (Abbink and van Kessel 2005). In places where the youth have no say in politics, they are now claiming their space through their actions and words on Facebook. The youth who show themselves in this new space, a space that is in fact theirs, are very active youth who want to take their destiny into their own hands and to create a space for themselves in the authoritarian state that Chad is: a state in which their parents' generation has not been able to create such space.

For these youth, Facebook posts are expressions of duress that we define as the personal internalization of, and reflection on, violence and oppression — an internalization and reflection 
that are the results of personal itineraries and experiences with an authoritarian regime, and that form these persons and their political agency.

\section{Acknowledgments}

Research for this article was conducted within the project "Connecting in Times of Duress:

Understanding Communication and Conflict in Middle Africa's Mobile Margins," funded by the Netherlands Organisation for Scientific Research (W01.70.600.001).

Mirjam de Bruijn is Professor of Contemporary History and Anthropology of Africa at Leiden University. She is an anthropologist whose work has a clearly interdisciplinary character with a preference for contemporary history and cultural studies. She focuses on the interrelationship between agency, marginality, mobility, communication, and technology. Email: m.e.de.bruijn@hum.leidenuniv.nl

\section{References}

Abbink, Jan, and Ineke W. M. J. van Kessel, eds. 2005. Vanguard or Vandals: Youth, Politics and Conflict in Africa. Leiden: Brill.

Bertho, Alain. 2016. "Jeunes chômeurs: Affrontements à N'Djamena-4 et 6 février 2016" [Unemployed youth: Clashes in N'Djamena-4 and 6 February 2016]. Anthropologie du présent [Anthropology of the present] (blog), 9 February. https://berthoalain.com/2016/02/09/jeunes-chomeurs-affrontements-a-ndjamena-4-et-6fevrier-2016.

Branch, Adam, and Zachariah Mampilly. 2015. Africa Uprising: Popular Protest and Political 
Change. London: Zed Books.

Camojet Tchad. 2018. Facebook profile, accessed 12 August.

https://www.facebook.com/camojet.tchad.

Chabal, Patrick. 2009. Africa: The Politics of Suffering and Smiling. London: Zed Books.

Coleman, E. Gabriella. 2010. "Ethnographic Approaches to Digital Media." Annual Review of Anthropology 39: 487-505. https://doi.org/10.1146/annurev.anthro.012809.104945.

Debos, Marielle. 2016. Living by the Gun in Chad: Combatants, Impunity and State Formation. London: Zed Books.

de Bruijn, Mirjam. 2008. “The Impossibility of Civil Organizations in Post-war Chad.” In Beside the State Emergent Powers in Contemporary Africa, ed. Alice Bellagamba and Georg Klute, 89-105. Cologne: Rüdiger Köppe Publishers.

de Bruijn, Mirjam. 2014. "The Itinerant Koranic School, Contested Practice in the History of Society and Religion in Central Chad." In Ordinary Violence and Social Change in Africa, ed. Jacky Bouju and Mirjam de Bruijn, 63-83. Leiden: Brill.

de Bruijn, Mirjam. 2015. "Student Leader Arrested in Chad." Counter Voices in Africa (blog), 27 August. https://mirjamdebruijn.wordpress.com/2015/08/27/student-leader-arrested-inchad.

de Bruijn, Mirjam, and Didier Lalaye. 2016. “An Engaged Chadian Artist’s Digital Itinerary Towards Political and Civic Success: Pitfalls of Oppression." In Digital Activism in the Social Media Era: Critical Reflections on Emerging Trends in Sub-Saharan Africa, ed. Bruce Mutsvairo, 141-57. Cham: Springer International Publishing. de Bruijn, Mirjam, and Han J. W. M. van Dijk. 2007. "The Multiple Experiences of Civil War in the Guera Region of Chad, 1965-1990." Sociologus 57 (1): 61-98. 
Ekine, Sokari, ed. 2010. SMS Uprising: Mobile Activism in Africa. Cape Town: Pambazuka Press.

Herrera, Linda. 2012. "Youth and Citizenship in the Digital Age: A View From Egypt." Harvard Educational Review 82 (3): 333-352.

Horst, Heather, and Daniel Miller. 2006. The Cell Phone: An Anthropology of Communication. Oxford: Berg.

Iwilade, Akin. 2013. "Crisis as Opportunity: Youth, Social Media and the Renegotiation of Power in Africa.” Journal of Youth Studies 16 (8): 1054-68. https://doi.org/10.1080/13676261.2013.772572.

Kaun, Anne, Maria Kyriakidou, and Julie Uldam. 2016. "Political Agency at the Digital Crossroads?" Media and Communication 4 (4). https://doi.org/10.17645/mac.v4i4.690.

Miller, Daniel. 2011. Tales from Facebook. New York: Polity.

Miller, Daniel, and Don Slater. 2001. The Internet: An Ethnographic Approach. Oxford: Bloomsbury Academic.

Peace Insight. 2015. "Collectif des Associations et Mouvements de Jeunes du Tchad (CAMOJET)" [Collective of Associations and Youth Movements of Chad (CAMOJET)] Last updated April. https://www.peaceinsight.org/conflicts/chad/peacebuildingorganisations/collectif-des-associations-et-mouvements-de-jeunes-du-tchad-camojet.

Rheinhold, Howard. 2002. Smart Mobs: The Next Social Revolution. New York: Basic Books.

Seli, Djimet. 2014. (De)connexions identitaires hadjeray: Les enjeux des technologies de la communication au Tchad [Identity (de)connections Hadjeray: The challenges of communication technologies in Chad]. Bamenda, Cameroon: Langaa RPCIG.

Theocharis, Yannis, and Will Lowe. 2016. "Does Facebook Increase Political Participation? 
Evidence from a Field Experiment." Information, Communication and Society 19 (10):

1465-1486. https://doi.org/10.1080/1369118X.2015.1119871.

TI (Transparency International). 2016. Corruption Perceptions Index 2016.

https://www.transparency.org/whatwedo/publication/corruption_perceptions_index_2016

. Berlin: TI.

UNDP (United Nations Development Programme). 2016. Human Development Report 2016:

Human Development for Everyone. New York: UNDP.

http://hdr.undp.org/sites/default/files/2016_human_development_report.pdf.

Vromen, Ariadne, Michael A. Xenos, and Brian Loader. 2015. "Young People, Social Media and Connective Action: From Organisational Maintenance to Everyday Political Talk.”

Journal of Youth Studies 18 (1): 80-100. https://doi.org/10.1080/13676261.2014.933198.

Waal, Alex de. 2006. "Chad in the Firing Line." Index on Censorship 35 (1): 58-65.

https://doi.org/10.1080/03064220600555776.

Waal, Alex de, and Rachel Ibreck. 2013. "Hybrid Social Movements in Africa." Journal of Contemporary African Studies 31 (2): 303-324.

https://doi.org/10.1080/02589001.2013.781320.

Wasserman, Herman (eds). 2010.Popular Media, Democracy and Development in Africa. London: Routledge

\section{Notes}

1 All translations are my own unless otherwise indicated.

${ }^{2}$ Slam is a form of urban poetry, often related to protest songs and text.

${ }^{3}$ In the course of my research, I came to discover the "working" of youth crosscutting countries. 
Exchanges for short courses on practical things such as web development, or on courses that are more leadership-oriented, are funded by international organizations. Some courses are also simply exchanged between acquainted groups. These youth networks are active.

${ }^{4}$ From 2015, Z. wrote texts about his experiences in Chad that we published on our website. Publishing on a site that is hosted in a foreign country seems to be without risk.

${ }^{5}$ This is enough to buy an average meal for one person in a street restaurant $(655$ CFA francs $=1$ euro).

${ }^{6}$ For security reasons, I cannot be precise here.

7 “Alternance" was a slogan used in Déby's campaign at election time to indicate progress and change in a positive direction. However, in popular critical discourses where the regime was accused of not having brought any change for the better, it became a kind of byword for the échec (failure) of the regime's politics. "Alternance" thus stands for critique of the regime's politics since 1990 . 